\title{
Analysis of the Set, Meaning, Range and Frequency of Lodging the Reasons for Judicial Protection Request
}

\author{
Tine Jurič \\ Police Station for Compensatory Measures Ljubljana, Slovenia \\ tine.juric@gmail.com
}

\begin{abstract}
The right to a legal remedy is one of the fundamental rights, which must be provided to every party involved in the proceedings (criminal, administrative, civil) which decide on the party's rights, obligations or legal benefits. In the field of misdemeanour law with regard to the fast track misdemeanour proceedings, the legislature refers to this remedy as the request for judicial protection. Its effectiveness at the level of the set of reasons and their frequency at lodging the request, with the aim of providing the best possible legal protection of offenders, is unexplored, and so an in-depth empirical, historical and normative research of the challenge against its lodging has been made, in particular of the range, meaning, scope and the frequency of the filing of the reasons challenging the lodging. The research established that the range of the challenging grounds for filing a request for judicial protection extends with the amendments to the Minor Offences Act and in this way provides a greater legal protection for offenders, and that most of them are filed due to a challenge on the grounds of erroneous and incomplete factual findings. This suggests that in this part of the fast track misdemeanour proceedings, most irregularities by misdemeanours authority are claimed. The results of empirical research utilizing the model of challenging the Police decisions regarding misdemeanours present the conduct of research, the methods used, as well as the baseline for a model of judicial protection against the decisions of the Police regarding the Minor Offences Act de lege ferenda.
\end{abstract}

Keywords: legal means, judicial protection request, fast track misdemeanour proceedings, reasons for requesting judicial protection

$J E L: K 14, K 23, K 42$

\section{Introduction}

Public law and its traditional model have had several shortcomings which have led to the conception of public law being defended on the grounds of human rights and fundamental freedoms. However, to prevent public bodies 
from abusing their authority, standards of legality have been introduced (Craig, 2003, p. 31).

In the Republic of Slovenia the legislation in the field of misdemeanours law has undergone the first serious constitutional and judicial review of compliance with the Constitution of the Republic of Slovenia (hereinafter CRS). The Constitutional Court in its decision no. U-I-56/06-31 stated that when dealing with misdemeanours within a single administrative and penal procedure, the rights to judicial protection (Article 23 of the CRS') and to a legal remedy (Article 25 of the $\mathrm{CRS}^{2}$ ) are guaranteed, since the decision on the judicial protection request (hereinafter JPR) provides judicial protection and at the same an appellate supervision of the decision of the body deciding on misdemeanour (Perpar et al., 2009, pp. 216-217). Similarly, the European Court of Human Rights in the decision Suhadolc against Slovenia, no. 57655/08, found that the applicant's case was dealt under a fast track procedure defined in the Minor Offences Act (hereinafter MOA-1), which means that a fine and penalty points may be imposed by regulatory authorities as well, while judicial protection is ensured by the appeal to the Court. This means that everyone has the opportunity to act against a single individual act (payment order, decision on the offence and the conclusion) of a misdemeanour authority by lodging a JPR and, if the latter is deemed unfounded, it shall be forwarded to the District Court in case assessment. In this way the right to a fair trial in accordance with Article 6 of the European Convention on Human Rights (hereinafter ECHR) is ensured.

In the field of misdemeanour law ${ }^{3}$ a set of reasons due to which a JPR may be lodged (Article 62 of MOA-1) is determined regarding the fast track misdemeanour proceedings (hereinafter fast track procedure) ${ }^{4}$ as well.

The reason why the JPR is given such importance can be attributed to the fact that the decision on it reflects the success of the body deciding on misdemeanors. ${ }^{5}$ It is also necessary to emphasize that, as a legal remedy, JPR

1 Each individual must be ensured that the allegations made against them and about their rights and obligations are, without undue delay, decided by impartial, independent and lawfully established courts. So the constitutional provision provides an effective protection of human rights also in misdemeanours proceedings, which establishes a special status and work of the Court (Gajzer, 2007, p. 157).

2 The right to appeal is a fundamental right of an individual, which derives from the principle of legality (Article 2 of the CRS) and the principle of equal protection of rights (Article 22 of the CRS), and is characteristical of the rule of law. Everyone is given the opportunity to contest the issued individual acts of all bodies of state and local authority, as well as the public bodies entrusted with authorities (Šturm et al., 2002, pp. 274-275).

3 The primary purpose of misdemeanour law is the protection of legal values, while the main goal is harmony, peace and order within the community (Kečanović, 2010, p. 1).

4 With MAO-1 the legislature created a fast track procedure, which was conceived as an administrative (misdemeanour) procedure at the first instance, pending before various, mainly administrative (misdemeanour) authorities. In continuation of this process, together with JPR it anticipated and regulated the judicial control over the decisions by offence authorities (Fišer, 2006, p. 49).

5 Transparency, administrative rights, open decision-making procedures, or improvement of the relations between citizens and state power are those forms which enable us to assess the practical standards of good governance (Nehl, 1999, p.17). 
is also some kind of a feedback on the effectiveness of the acquis in practice, and not just a tool of legal protection. ${ }^{6}$

The purpose of the paper is to present an analysis of the open procedural issues on the expansion of the set of reasons and on the importance of challenge for lodging a JPR in connection with the Amendments to MOA-1, and consequently, on providing greater legal protection of the offenders. Based on quantitative and descriptive methods and the induction-deduction method as well as sampling, I present the starting points for the model of legal protection against the decisions of the Police on the MOA-1 de lege ferenda. Through analysis and study I examine whether the set of reasons for filing the JPR is actually expanding along with the MOA-1 amendments, and whether the trend of the frequency of lodging JPR varies between the chosen samples in different periods at different police stations.

\section{Analysis of the Expansion of the Set of Reasons for Challenge When Lodging Judicial Protection Request}

Upon entry into force of MOA-1, the Article 62 had only four sets of reasons which the beneficiary may invoke individually or all together in JPR. Then the Article 62 of MOA-1 reads as follows: "The decision by a misdemeanour body may be challenged by the JPR:

- if the decision violates the substantive provision of this Act or the regulation which defines the offence;

- if there has been a violation of the procedural provisions because the decision has not been made by the competent body, because the offender was not presented with an opportunity to be heard about the offence, because a person who under the law should be excluded or was excluded had been involved in the decision making or conduct of the procedure, because the provisions on the use of language in the proceedings have been violated, because the order of the decision is not clear or is contradictory within itself, or because the decision does not contain all the prescribed items;

- due to erroneous and incomplete factual findings, where new facts may be stated and new evidence proposed in the JPR only if the JPR applicant proves as probable that, without the fault on his or her part, the applicant could not include them in the fast-track procedure;

- due to the sanctions imposed, asset recovery and costs of the proceedings and the decision of a property claim."

Such an arrangement, according to the definition of the procedure in respect to the JPR as set out in Article 65 of the MOA-1 did not allow the examination of the lodged JPR ex-officio (according to Article 159 in relation to the

6 Legal certainty and the principle of fair treatment in proceedings before courts and other state bodies are also among the fundamental elements of the rule of law (Maunz \& Dürig, 1991). 
third paragraph of Article 59 of MOA-1), rather the examination was limited solely to the reasons established in the JPR (e.g. any fundamental defect of procedure or substantive law). Interesting in this respect is the decision of the Supreme Court, which in the reasoning of the judgement, no. IV Ips 41/2006, inter alia, stated, that the court "shall assess the JPR claims and comment on whether the JPR provided established violations or not", and therefore did not indicate that the court shall, in addition to the foregoing assessment, conduct an official examination of a decision in respect to certain violations which may constitute the grounds for lodging JPR. The same is true for the misdemeanours body which tested only those violations claimed by the beneficiary. In doing so, however, the body was not enabled to correct its mistakes in the cases when it found a violation of a right which the beneficiary did not invoke.

The practice of district courts was very heterogeneous in this respect, which did not contribute to legal protection of citizens and the provision of their equality before the law (Prus, 2007, p. 201). All this reflected large anomalies in the processing of JPR, but only the Act Amendment MOA-1E somehow put everything into place. It added a new fourth reason of Article 62 of MOA-1, which reads as follows:

- "if the decision is based on a piece of evidence on which, according to the provisions of this Act, it cannot be based, or which was obtained in violation of the human rights and fundamental freedoms defined by the Constitution."

The previous fourth reason became the fifth reason of Article 62 of MOA-1. From then on, Article 62 of MOA -1 has not been amended or supplemented.

The most important change brought by the said Amendment was the implementation of Article 62. a of MOA-1, which was later supplemented or amended twice, namely by Act Amendments MOA-1F and MOA-1G. The first paragraph of Article 62. a of MOA-1 introduced violations which should be examined ex officio, which means that they must be considered irrespectively of whether the beneficiary claims them in the JPR or not. This defined more clearly the duty or obligation by both, the misdemeanours body as well as the court, in substantive examination of JPR.

Now, after all the changes, the first paragraph of Article 62.a of MOA-1 reads: "When processing a JPR, the following shall be always examined ex-officio:

- whether the decision has been made by the competent body (changed by the Act Amendment MOA-1G)

- whether there is a violation of substantive provisions of this Act or Regulations which define the offence (added in Act Amendment MOA$1 \mathrm{~F}$ and later modified by the Act Amendment MOA-1G)

- whether the prosecution is time-barred (added by Act Amendment MOA-1F) 
- whether the offender was given the opportunity to make a statement about the offence,

- whether the order of the decision is intelligible and

- whether a decision is based on a piece of evidence on which it cannot be based according to the provisions of this Act, or which was obtained by violating human rights and fundamental freedoms set out in the Constitution".

From the above it follows that the set of reasons for challenging the decision and which serve as a basis for lodging a JPR, expands with the amendments to MOA-1, and in this way provides a greater legal certainty to the perpetrators. This means that now, with all the amendments described, also the fast track procedure actually provides an effective legal remedy and ensures the right to a fair trial. ${ }^{7}$

\section{Investigation of the Meaning of the Reasons for Challenge When Lodging a Judicial Protection Request with Analysis of the Cases from Case Law}

\subsection{Violation of Substantive Provisions of the Minor Offences Act or the Regulation That Defines the Offence}

Violation of substantive provisions is specified as the case when the misdemeanour authority wrongly or incorrectly applies a legal act or other regulation, as well as the case when none was used. Substantive legal provisions are comprised in the first part of MOA-1 (the general part of substantive law), which covers the basic provisions: the provisions on offence and the responsibility for it, the provisions on penalties, recovery of criminal assets, educational measures and sanctions for juveniles, and general provisions setting forth time limits. The special part of substantive legal provisions is set out in the acts, governmental regulations or decrees governing local communities, which define certain acts or omissions as an offence, determine the signs of prohibited conduct, and prescribe or determine sanctions for such acts (Orel, 2008, pp. 28-29).

The Supreme Court, in its judgement, no. IV Ips 41/2013, also stated: "The Chief State Prosecutor reasonably exercises also the material breach of the provisions of the law under item 4 of Article 156 of MOA-1, since in respect to the offence which is the subject of a payment order, the Court applied a rule

7 In the empirical part of his master thesis entitled Analysis of Challenging Police Decisions in Fast Track Misdemeanour Proceedings, the author of the article analysed also the proportion of the JPR rejected before the court, and found that from 2006 to 2011 the proportion fell by about $18 \%$ (in 2006, this proportion was the highest $-78.16 \%$, while in 2011 it was the lowest $-60.72 \%)$. This means that the position of the JPR beneficiaries has actually improved, since under the current regime of MOA-1 more reasons are available for lodging the request (Article 62 of MOA-1). The misdemeanours body as well as the court are now obliged to examine certain reasons, whether there was a violation or not, irrespectively of whether the beneficiary has listed the reasons in the request (Article 62 of MOA-1). 
which it should not have applied by failing to change the legal definition of the driver's offence in the operative part of its judgement. It is also right when stating that the court had an ex-office obligation to establish the violation of the substantive provisions of MOA-1, namely, the second paragraph of Article 57 of MOA-1, since the payment order contained no legal definition of the driver's offence, and to change the legal definition of the offence of the driver in the operative part of its judgement, as well as adequately clarify its decision. The offence of the driver is defined in the second paragraph of Article 125 of RTA-2." In the flood of laws and other regulations, which define the various offences (traffic legislation, offences in the field of public order and peace, weapons, illegal drugs...) it can easily occur that an incorrect regulation is applied, or that the violator is accused of an offence under the wrong provision of that regulation. The problems are caused primarily by the legal definition of the offence to the natural person in relation to the person responsible. That is - when a natural person also acts in the role of the responsible person, and under which provision is then this person sanctioned (under the provision for natural or responsible person). caused by the provisions which, in addition to their disposition, also contain definitions of other offences. Thus, for example, the provision of Article 20 of the Act on Criminal Offences against Public Order and Peace (APOP-1) ${ }^{9}$ covers the legal definitions of the Articles $6,7,12,13$ or 15 of the APOP-1. Sometimes it happens that, in addition to the fine for an offence under Article 20 of APOP-1, a violator is also punished with a fine pursuant to Article 7 of APOP-1 (indecent behaviour in a public place). Such conduct of a misdemeanour body constitutes a violation of constitutional rights since the offender is punished twice for the same offence (Article 31 of the Constitution). The fine may be imposed only for an offence under Article 20 of APOP-1, if it is possible to confirm that it was performed with elements of intolerance. Despite the fact that even constitutional rights may be violated, the misdemeanour authority has the possibility to eliminate them, of course, if it notices them by itself ${ }^{10}$ or if the violation is brought to its attention ${ }^{11}$. The aim of any misdemeanours body is that its behaviour, decision making and procedure management are lawful and proper.

8 In more detail in the judgments of the Supreme Court no. IV Ips 75/2013 dated 29. 8. 2013, IV Ips 85/2013 dated 29. 8. 2013 and IV Ips 113/2013 dated 21.11. 2013.

9 If the offences referred to in Articles 6, 7, 12,13 and 15 of this Act have been committed to incite ethnic, racial, sexual, ethnic, religious, political intolerance or intolerance of sexual orientation, the perpetrator shall be punished by a fine of at least SIT 200.000 (EUR 834.58).

10 Rehabilitation is possible after finality by lodging an extraordinary legal remedy - elimination or amendment of the decision on the offence following a proposal by the misdemeanours authority (hereinafter referred to EADPMA).

11 With JPR or with a proposal for EADPMA. 


\subsection{Violation of the Provisions of the Procedure}

It is considered to be a violation of the provisions of the procedure if:

- decision has been made by an incompetent authority,

- the offender's right to be heard has been infringed,

- a person who under the law should have been excluded, or was excluded from it, has been involved in the decision making or the conduct of the procedure,

- the provisions on the use of language in the proceedings have been violated,

- the operative part of the decision is incomprehensible or contradictory within itself,

- the decision does not contain all the prescribed elements.

In the JPR process it must be assessed whether the decision has been made by a competent authority. Misdemeanour bodies are very numerous and it may occur that they cross the boundaries of their areas of work, especially, if the delimitation of competences is not entirely clear. The procedural regulations usually require very strict compliance with substantive jurisdiction, while regarding territorial jurisdiction they are less strict, especially if there is no objection in this direction and if the procedure has already reached progressive stages in the process. Granting a JPR ex officio due to the fact that a decision was made by a territorially incompetent body or bodies would seem excessive (Fišer et al., 2009, p. 379).

The Supreme Court in its judgement, no. IV Ips 58/2007, decided, that before deciding on a JPR against a payment order, the offender needs to be informed of the key incriminating facts and must be allowed to be heard on the subject, regardless of the fact that the procedural provisions of the MOA-1 do not explicitly require it. Similarly, the European Court of Human Rights in its judgement Šild vs. Slovenia, no. 59284/08, also stated: "Although Article 6 of the ECHR does not provide for specific forms of service of documents (see Bogonos vs. Russia, (dec.) no. 68798/01, 5 February 2004), the general concept of fair trial, encompassing the fundamental right that the proceedings should be adversarial, requires that anyone who is charged with an offence, has the right, under Article $6 \S 3$ (a) of the ECHR, to be informed of the nature and cause of the accusation against him. The right of access to court under Article $6 \S 1$ furthermore entails the entitlement to receive adequate notification of administrative and judicial decisions (see, inter alia, generally Hennings vs. Germany, 16 December 1992, Series A no. 251-A, and Sukhorubchenko vs. Russia, no. 69315/01, §§ 53-54, 10 February 2005), which is of particular importance in cases where an appeal may be sought within a specified time-limit." The Act Amendment MOA-1E set out the still existing conditions for obtaining the offender's statement before the decision on the offence and the content which must be made known to the offender (Article 
55 §§ 2-3 of MOA-1). Thus, as has been previously determined, the offender who at the site of detection of an offence cannot provide a statement about the offence, must be, before issuing a decision, sent a written notice with the instruction and be provided with the possibility to be heard. The same applies if immediately upon finding or dealing with the concrete matter the misdemeanour authority could not inform the offender of the nature of the complaint and his or her rights in order to give the offender an opportunity to "prepare a defence." It is expressly provided that a decision on the offence cannot rely on the statement of the offender, if he or she was not informed in accordance with MOA-1 of his or her rights in the proceedings (Article $55 \S 2$ of MOA-1). Given the punitive nature of misdemeanour proceedings, the rights of the offender should be protected also when issuing the payment order. An authorized officer (hereinafter $\mathrm{AO}$ ) who issues the payment order to the offender and serves it on the spot, is obliged to inform the offender about committing the offence immediately upon delivery, which is characterized by the payment order (first paragraph of Article 57 of MOA-1) (Orel, 2008, p. 30). If a payment order cannot be served to the offender at the location of the offence, it is necessary that prior to its issuance and service the offender has the possibility to make a personal statement about the offence under the provisions of Article 55 of MOA-1, while the payment order must also include a brief description of the offence and a summary of the offender statement (Article 57 \& 2 of MOA-1). This ensures the offender's right to JPR, because only if the offender is informed about the findings by the $A O$, the offender can challenge the substantive findings of the misdemeanour authority. An offender may also learn about the nature of the obtained evidence by reviewing the file at the offence authority (Article 82 of the APA in relation to Article 58 § 1 of MOA-1).

The infringement due to the fact that a person has been involved in the decision making or the conduct of the procedure who under the law should have been excluded, or was excluded from it, does not only apply to the individual AO of a misdemeanour authority, but to all persons who have been involved in managing the procedure and decision-making. These may be several, so the scope of this infringement is quite large. Which is understandable for the exemptive reasons, but rather less for the exclusionary ones.

Considering the specifics of some of the fast track procedures, it is estimated that the provisions providing for the use of the offender's language in the fast track procedure are often breached, and their consequences underestimated. The right to use one's own language is a component of the right to a fair trial. For example, of what use is the offender's right to be heard, if the offender does not understand the proceedings, of what is he or she accused and what is the basis for the complaint, while in addition the offender is also unable to express his or her thoughts in a language which he or she masters (Fišer et al., 2009, p. 380). 
Intelligibility of the decision does not only relate to its clear content, but also provides that the description includes all specific circumstances that concretize the material scope of the offence. Abstract description of the act is sufficient only when the nature of matter renders concretization unsound, but otherwise the operative part must also include the concretization of the material scope. It is essential that the specific circumstances are described in such a way that an examination is possible which must answer the question: "Do the specific circumstances described in the operative part realize all the abstract legal signs of the offence?" The importance of indicating the place and time of the offence and the relevant facts must be particularly emphasized, since the absence of these in the description of the act constitutes unintelligibility of the decision on the offence (incorrect or defective indication of the place and time and decisive facts is a question relating to the factual state of the offence) (Orel, 2008, p. 30-31).

In the judgement no. IV Ips 71/2007 the Supreme Court ruled out that the imprecision of a police officer who partly entered the violated provision of the RTSA-1 in the wrong part of the six sections provided for this purpose on the form of a payment order, due to which the record suggested that the offence is pursuant to Article 115 \& 5 Item 4 of RTSA-1, which does not exist, is not a mistake which would render the "operative part" of the payment order unintelligible. Regarding the nature of the complaint, there was no lack of clarity in the procedure, which is also established by the fact that the perpetrator explicitly wrote in the JPR that "the police officer fined him for the breach of Article $115 \S 4$ of RTSA-1 and not for the offence under the $\S 5$ of the same Article". Mistakes are commonplace in the operation of offence authorities. All mistakes, except for those that have been found in the operative part of an individual act, are corrected upon their finding (upon perpetrator's advice, one's own notice) by an order on mistake correction. If the misdemeanour authority detects a mistake in the operative part of an individual act, it can be repaired only after finality by filing an extraordinary remedy EADPMA. However, if the mistake is brought to the authority's attention by legal means (JPR), it shall first abolish its original decision and then take the right decision (issue a new individual act, stop the proceedings, make a suspensory proposal or suggest other misdemeanour authority).

The components of a written decision on the offence are otherwise provided by Article 56 of MOA-1, but nevertheless, it will not be always easy to determine whether a decision contains everything that it should, or not, or whether this applies only to the formal elements of decision (Introduction, Operative Part, Explanation and possibly even Legal Instruction and identification tags), or whether it entails everything that the components should include by nature. In the latter case, that would constitute an extremely broad reason for filing JPR and probably there are not a lot of misdemeanour authorities' decisions that would withstand a somewhat strict examination. Among the components of decision it is necessary, however, to prioritize and take 
into account in particular those which on the one hand determine the offender, while on the other they define the action that is characterized as the offence (Fišer et al., 2009, pp. 380-381).

\subsection{False and Incomplete Factual Findings}

The third reason constituting the grounds for lodging a JPR relates only to the decisive facts. These are the facts (substantive and procedural legal relevant facts), which present the direct foundation for the application of the law (substantive and procedural). The key facts represent the factual state of the offence. ${ }^{12}$ We consider the determination of factual state to be erroneous if, from the circumstances identified by the misdemeanour authority as proven, we cannot derive conclusions on the grounds of which the existence of an offence could be determined, or when the misdemeanour body has wrongly assessed the evidence, deciding about it differently than it should from the derivative evidence by a logical conclusion. However, determination of factual state is regarded as incomplete if the misdemeanours authority has not considered relevant circumstances, or if it has abandoned their determination. The offence proceedings are subject to the limitation of new facts and proposal of new evidence. This limitation must be brought to the offender's attention already by the misdemeanours authority, before taking a decision on the offence or issuing a payment order (Article $55 \S 2$ of MOA1). Its purpose is to avoid unnecessary delay in the proceedings at all stages of the fast track procedure, which is still a very common aim of the offenders undergoing such procedure (Orel, 2008, pp. 31).

Higher Court of Celje in its decision no. VSC decision Prp 241/2013, ruled: "The determination of the circumstances which shall deem an offense as a minor offence, as defined in Article 6 of MOA-1, falls within the framework of establishing the factual state. If the court of first instance finds and assesses them, but the complainant (misdemeanours body) disagrees with the determination of the court and offers its own assessment of differently determined and assessed circumstances, this is an issue of the correct assessment of the factual state." Only when the misdemeanours authority establishes the factual state of the offence committed, it can credibly determine, whether it has collected enough facts and evidence that a person has committed an offence, or the collected facts, evidence and circumstances show that the offence was committed in such circumstances which render it particularly minor, and no adverse consequences have or will have ensued. The worst thing for a misdemeanours authority is if the district court upon examining the JPR establishes that the factual state was determined in an incomplete or incorrect way, which may have the effect that the authority's

12 Even in the cases where AOs personally notice offences, it is reasonable and permissible to use the reason of erroneous and incomplete findings of the factual state for lodging the JPR, as well as the alleged offender succeeding with it. We must proceed from the fact that the AOs working at offence bodies are only people, who are fallible, and acknowledge the fact that the technical devices and resources do not always perform impeccably. However, it is not possible to exclude even the cases where the AOs abuse their position (Jakulin, 2007, p. 55). 
decision is changed, and in the end, may even stop the whole procedure. The authority can attribute such an outcome only to its own shortcomings in conducting the fast track procedure, since it is more than obvious that it did not comply with the MOA-1 and case law. It is particularly important that when making its decisions, the authority takes into account the views of the alleged offender and explains why it did not introduce the evidence proposed by the offender, or why did it consider it to a smaller extent (ensuring the constitutional right to present evidence to the offender's favour - the third indent of Article 29 of CRS). A fast track procedure conducted in this way can prevent or restrict the beneficiary to lodge a JPR.

\subsection{Relying on a Piece of Evidence on Which a Decision Cannot Rely According to the Provisions of Minor Offences Act, or Which Was Obtained by Violating Human Rights and Fundamental Freedoms Set out in the Constitution}

It is possible to infer the severity of violation from the fact that a breach of this reason in the appeal proceedings under the ordinary course of judicial proceedings is deemed to be an absolute breach of the essential procedural provisions (Item 6 of Article $155 \S 1$ of MOA-1). This means that only its existence needs to be proved, and not also that its infringement impacted the legality of the decision.

The stated provision is similar also to the violation of criminal procedure (Item 8 of Article 371 \& 1 of CPA). Of course, the infringement of reason between the MOA-1 provision and the CPA provision cannot be deemed equal. The situation is not controversial when the rule/decision is based on the evidence obtained in violation of constitutional human rights and fundamental freedoms, or on the evidence for which the law provides that a rule/decision must not be based on. Here, one should only follow the norms that prohibit the use of such evidence (e.g. Article $110 \S 4$ of MOA-1, or Article 18 § of (PA). Although MOA-1, unlike CPA, does not expressly provide that the evidence obtained on the basis of illicit evidence (fruit of the poisonous tree doctrine) should not be used, there is no valid reason for their differentiation.

The main difference with regard to potential violations when the evidence is obtained in violation of the constitutionally provided human rights and fundamental freedoms (from illegal acquisition of material evidence to obtaining personal evidence), can be found in their safety measures. In earlier proceedings of the applicant they are significantly looser than in pretrial proceedings. Paying attention and responding to these violations is expected from the first instance judge in particular, and later also during the eventual appeal. Despite this, the MOA-1 contains no provision on the rule of exclusion, under which it would be necessary to exclude an inadmissible evidence, as well as the judge who came into contact with it (psychological contamination). Even with the use of such evidence it is possible to ensure the right to a fair trial at this stage of criminal law (Fišer et al., 2009, pp. 691-695). 
In the regulation of fast track procedure this argument is not specified as one of the possible violations of procedural provisions, but is rather defined as a separate reason for which a JPR may be lodged (fourth indent of Article 62 § 1 of MOA-1). MOA-1 specifically provides that the decision of the misdemeanour authority should not rely on the statement of the offender who was not informed of his rights under Article $55 \S 2$ of MOA-1. It also should not rely on the evidence if the instruction on the rights has not been entered in the minutes or in the official notes, or in the notice to the offender, in order that the offender makes a statement regarding the facts and the circumstances of the offence. In addition, the decision should not rely on the statement of the offender who was detained because he or she was caught committing an offence under the influence of alcohol or other psychoactive substances, and was not informed about the rights (Article $109 \S 3$ and Article $110 \S 3$ of MOA1 and Article 24 of Act of Rules in Road transport) (Orel, 2008, pp. 31-33).

Higher Court of Ljubljana in its judgement, no. VSL PRp 571/2009, inter alia, stated: "The first instance court based its decision on the offender's testimony at the hearing, where she stated that in an interview by a police officer she had indeed confessed to him due to her confusion that she had driven her father's vehicle during the critical period, and on the testimony by the police officer, who confirmed her testimony. From the judgement under appeal and the information in the file it cannot be inferred that a police officer would, prior to the interview, inform the accused party in the process of collecting information about the offender about her constitutional right to not incriminate herself, or her family, or to confess guilt. The judgement of the first instance court thus relies on illicit evidence." The Supreme Court, in its judgement, no. IV Ips 117/2008, also concluded similarly: "The official notice about the suspect's statement which was given to the Police at the site of the offence, before the suspect was informed of his constitutional right to remain silent or of his privilege against self-incrimination, cannot be used as evidence in a procedural sense, on which the judgement about the offence could rely, since it presents illicit evidence according to Item 6 of Article 155 $\S 1$ of MOA-1." The featured rulings describe different situations when the judgement relied on inadmissible evidence. Precisely the constitutional right, which determines the privilege of not incriminating oneself or to remain silent, is the first in a series of rights the infringement of which constitutes the collection of illicit evidence. If an offender or a witness are not informed of this right prior to the collection of information or their hearing, their statements, as evidence obtained on the basis of these statements, are rendered illicit and the decision shall not be based on them. This is given too little importance in the fast track procedures, since it is still too often violated. This refers primarily to discussions about the committed offences, when, prior to their initiation, witnesses or offenders had not been alerted to the privilege of selfincrimination or incrimination of their relatives, and the right to remain silent. 
Analysis of the Set, Meaning, Range and Frequency of Lodging the Reasons for Judicial Protection Request

\subsection{The Sanctions Imposed, Asset Recovery and Costs of the Proceedings and the Decision of a Property Claim}

As a rule, the misdemeanours authorities impose fines in the amount of the prescribed minimum, unless they have the power to impose fines within a range. In this case, the offender is able to claim a fifth reason in the JPR the circumstances which the misdemeanours authority did not consider even if it should have considered them, or which the authority did not properly consider in the selection and assessment of the sanction. After the JPR has been submitted, irrespective of the type of decision (Article $63 \S 5$ of MOA1), the misdemeanours authorities have a limited possibility of a different imposition of sanctions. Pursuant to the powers, they may opt for a reprimand if there exist reasonable grounds (Article 21 of MOA-1), but they can also stop the fast track procedure against the offender after abolishing their decision (Article 136 in relation to Article $58 \S 2$ of MOA-1). Otherwise, they must (generally) refer the matter to the court. The misdemeanours bodies do not have the authority to mitigate the prescribed sanction, that is to impose a fine below the limit prescribed for this offence. The mitigation power is reserved for court only (Article $26 \S 6$ of MOA-1).

In its judgment no. IV Ips 28/2014, the Supreme Court also stated: "With the act amendment MOA-1G, the responsibility of legal persons, sole proprietors individuals and individuals who independently perform an activity, in the event of bankruptcy or closure is regulated by Article 14. b of MOA-1. It should be noted that the concept of termination does not only entail the termination with bankruptcy, but also other possible forms of termination of legal persons, for example, voluntary and compulsory liquidation, deletion from the register without liquidation, merger, division, transfer of assets, change of legal form, etc. (Jenull and Selinšek 2011, p. 53-54). According to this provision, the legal entity which ceases to exist before being issued a decision or judgement regarding an offence is recognized as responsible for the offence, and the penalties for the offence and assets recovery are imposed on the entity that is its legal successor, if the managerial or supervisory authority or the business operator had known of the offence committed. If he or she did not know of it, only confiscation and assets recovery may be imposed upon the successor." It has to be noted that fast track procedure is not permitted when deciding on a property claim. This means that the decision about it is always taken at a district court in special proceedings. In the case, when asset recovery is not specifically conditioned, or the condition is optional, a district court also decides about the seizure. Otherwise, when a certain obligate requirement is provided, the decision on assets recovery falls under the authority of a competent misdemeanours body. As for the costs of the procedure, their assessment (e.g. court fee) or payment (e.g. as an award to an attorney) always falls under the authority of a competent misdemeanours body (from Article 143 to 146 of MOA-1). 


\section{Study of the Frequency of Lodging Reasons for Judicial Protection Request}

The main objective of the study is to determine the frequency of implementation of each reason in JPRs. Such a survey hasn 't been conducted yet and it may show, in relation to the complaints of beneficiaries, which reason misdemeanours authorities supposedly most frequently violate in making their decisions. The findings may assist a misdemeanours authority in its subsequent operation, because in this way it learns where it can still improve its performance and by doing so diminish the number of beneficiaries claiming infringement of an individual reason.

Before I could tackle the studies and analyses themselves, I had to collect data by myself, since neither Police nor the Ministry of Justice keep records regarding the frequency of application of individual reason. Thus, if I wanted to do a primary study, I had to decide by myself where I would collect the data. After obtaining the authorisation, I visited two urban police stations (Center, Moste) and two district police stations (Kočevje, Ribnica), which fall under the Ljubljana Police Directorate ${ }^{13}$. At each station, I reviewed the content of the JPRs which were filed against individual acts (decisions on the offence, payment orders, orders), and thus found the reasons for their lodging. The study included all JPRs, irrespective of the type of the established offence (road traffic, public order and peace, weapons, illegal drugs...). I recorded the found reasons on the form prepared beforehand, and for the urban stations, I collected a random sample of 150 units out of the entire population, while the datasets for regional stations were different, since I reviewed all of their individual acts. ${ }^{14}$ This was not possible at urban stations, since the number of the filed JPRs in a given year was close to 1000 or even more. When collecting samples at these stations, I was not paying attention to the month of each year in which the JPR was lodged, and whether it was lodged against a payment order, a misdemeanours decision or an order, whether it was lodged against offences in the field of traffic law, public order and peace, weapons, illegal drugs, alien citizen problems... rather, when I was in the archives, I randomly selected and read the binders which stored archival documentation (I decided on site which binders I would take and review the archival documentation). Because each police station has its own way of keeping archival documentation, ${ }^{15}$ choosing documents by following a certain

13 I chose these police stations with the regard to the comparable volume of their work area.

14 The collected data sets of the lodged JPRs against individual acts, by police station, within the selected time-frame, are shown in the graphs. The number of JPRs filed by individual reason for challenging the decision is indicated above each column in a given year. E.g., the Graph 1 shows that in 2007 there were 110 JPRs lodged due to erroneous and incomplete findings of fact, and that no JPR was lodged due to inadmissible evidence.

15 The archives are managed in a way which enables that the decisions on offence and payment orders against which a JPR was lodged are managed separately, while in some places they are managed together, or in others they are kept with the rest of archival documents for which a JPR has not been lodged. In the meantime, document filing and recording system has also changed, because Police started using a new software. These are the main reasons that a systematic choice was not possible. 
system was not possible. When I gathered a sample of 150 units for each year, I continued collecting samples in the same way for the next year. ${ }^{16}$ The study covered the period 2007-2011. From the data collected, I initially conducted a study for each separate police station, and in the conclusion, I compared the results between the stations and summarized the common findings.

\subsection{Police Station Center Ljubljana}

For the Police Station Ljubljana Center (hereinafter PS Center), I randomly selected a sample of 150 units for each individual year (2007-2011) from the population of all individual acts where a JPR has been filed.

Graph 1: Study of the filed JPRs by the number of the individual reason for the period 2007-2011 at PS Center

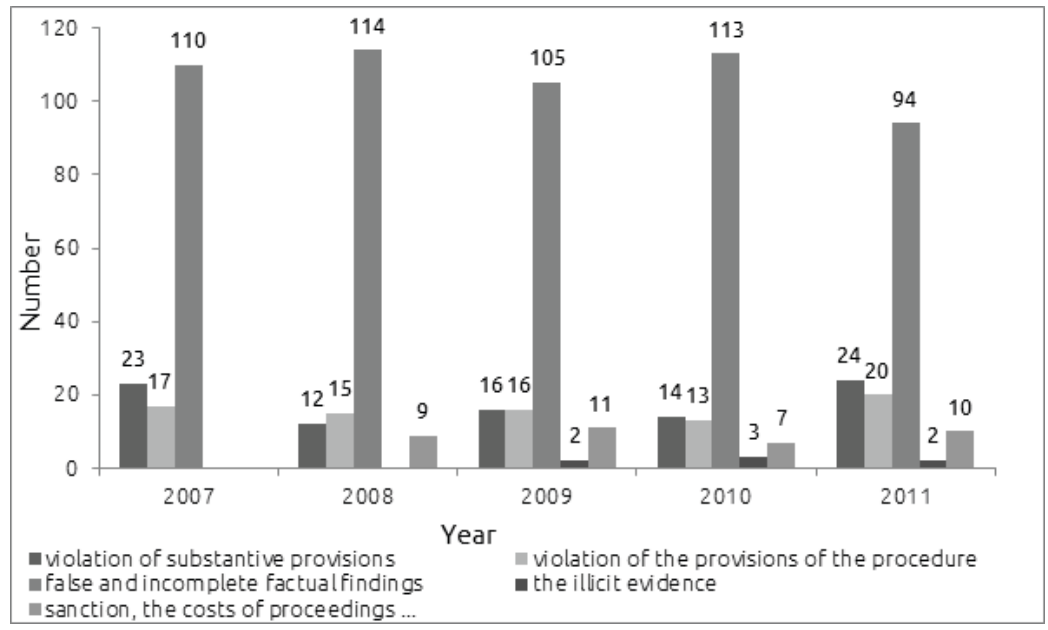

Source: JPRs filed against individual acts of the misdemeanours authority PS Center

The Graph 1 shows that the reason of 'false and incomplete factual findings' is most frequently exercised by the beneficiaries in their JPRs. Its representation during the period 2007-2010 is somewhere between $70 \%$ and $76 \%$ with regard to all JPRs. A small decline is noticeable only in 2011 , when it is established - if compared to previous periods - in only $62 \%$ of all JPRs. Regarding its frequency of exercise in JPRs, the reason of 'violation of substantive provisions' is placed second during almost all time periods. Only in 2008, the reason of 'violation of the provisions of the procedure' takes over, but they become equally frequent in 2009. The reason of 'violation of substantive provisions' reaches its lowest percentage in 2008, because it is established only in $8 \%$ of all JPRs, and is highest in 2011, when it is established in $16 \%$ of all JPRs. When regarding all time periods in a comprehensive manner, the third most frequent reason is the 'violation of the provisions

16 In this context, many people will be raising the question whether the sample of 150 units is representative considering their random selection. The answer will be presented in Section 4.5 Comparison of Results. 
of the procedure'. In 2008, when it ranked second, before the reason of 'violation of substantive provisions', it represented 10\% of all JPRs. In 2009, when the two reasons were even, they were both exercised in $10.7 \%$ of all JPRs. The years 2008 and 2009 do not represent its minimum or maximum, because in 2010 it was exercised in only $8.7 \%$ of all JPRs (minimum), while in 2011 it was exercised in $13.3 \%$ of all JPRs (maximum). The reason of 'sanction, the costs of proceedings...', which occupies the fourth place, was not exercised in any JPR in 2007. In other periods of time, the beneficiaries exercised it the least in 2010 - in only $4.7 \%$ of all JPRs, and most often in 2009 - in $7.3 \%$ of all JPRs. Also, the reason of 'the illicit evidence', which occupies the last, fifth place, was not exercised in any of the JPRs in the years 2007 and 2008. In the remaining time frames it is established only in $1.3 \%(2009,2011)$ ог $2 \%$ (2010) of all JPRs.

\subsection{Police Station Ljubljana Moste}

For the Police Station Ljubljana Moste (hereinafter PS Moste), I randomly selected a dataset of 150 units for each individual year (2007-2011) from the sample of all individual acts where a JPR has been filed.

Graph 2: Study of the filed JPRs by the number of the individual reason for the period 2007-2011 at PS Moste

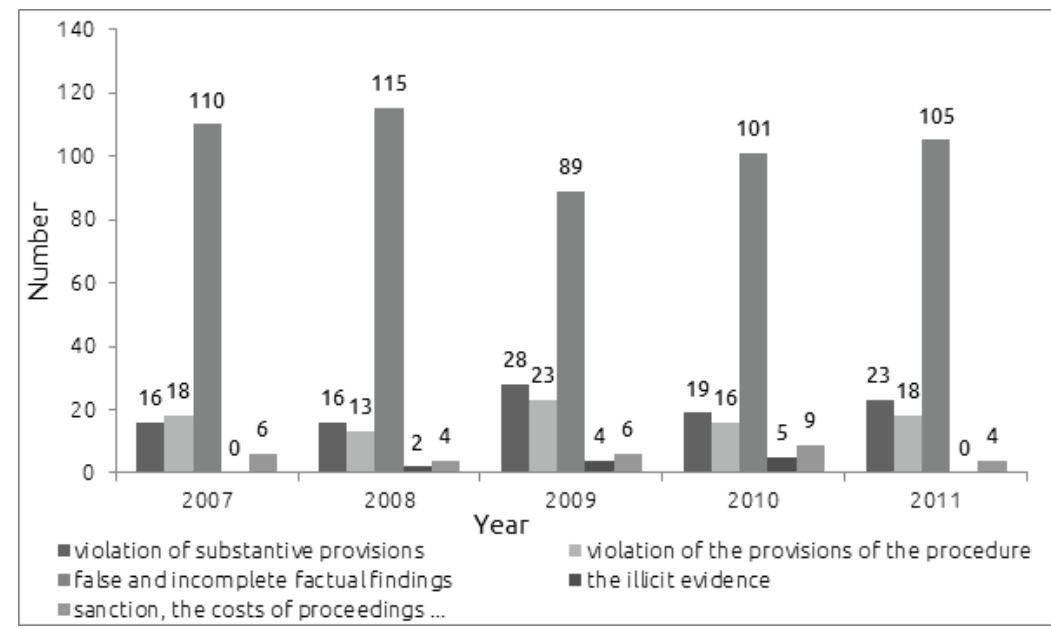

Source: JPRs filed against individual acts of the misdemeanours authority PS Moste

The Graph 2 shows that the reason of 'false and incomplete factual findings' is most frequently exercised by the beneficiaries in their JPRs. In 2009, it is established only in $59 \%$ of all JPRs, while in the remaining periods of time it is established in many more JPRs, namely, in between $67 \%$ and almost $77 \%$ of all JPRs. By its frequency of being claimed, the reason of 'violation of substantive provisions' ranks second in almost all the studied periods, except for 2007, when the reason of 'violation of the provisions of the procedure' is more frequent. The reason reaches its lowest percentage in the years 2007 
and 2008, because it is established only in $10.7 \%$ of all JPRs, and its highest in 2009 , when it is established in $18.7 \%$ of all JPRs. In the third place, in almost all periods of time, except in 2007, when it was ranked second, is the reason of the 'violation of the provisions of the procedure'. In that year, and in 2011, it represented $12 \%$ of all JPRs. This is a medium value, since the reason is least established in 2008, in only $8.7 \%$ of all JPRs, and most often in the year 2009 , in $15.3 \%$ of all JPRs. Regarding the reason of 'sanction, the costs of proceedings...', which occupies the fourth place, its minimum was reached in 2008 and 2011, when it was established only in $2.7 \%$ of all JPRs, while its maximum occurred in 2010, when it was established in $6 \%$ of all JPRs. The reason of 'illicit evidence', which occupies the last, fifth place, however, was not claimed between the years 2007 and 2011 in any JPR. In the time period 2008-2010, it is established in between $1.3 \%$ and $3.3 \%$ of all JPRs.

\subsection{Police Station Kočevje}

Given the fact that the Police Station Kočevje (hereinafter referred to as PS Kočevje) had received much fewer JPRs than the urban police stations, I was able to examine all of its individual acts against which a JPR was filed. That is how I got different datasets for each year (2007-2011) here.

Graph 3: Study of the filed JPRs by the number of the individual reason for the period 2007-2011 at PS Kočevje

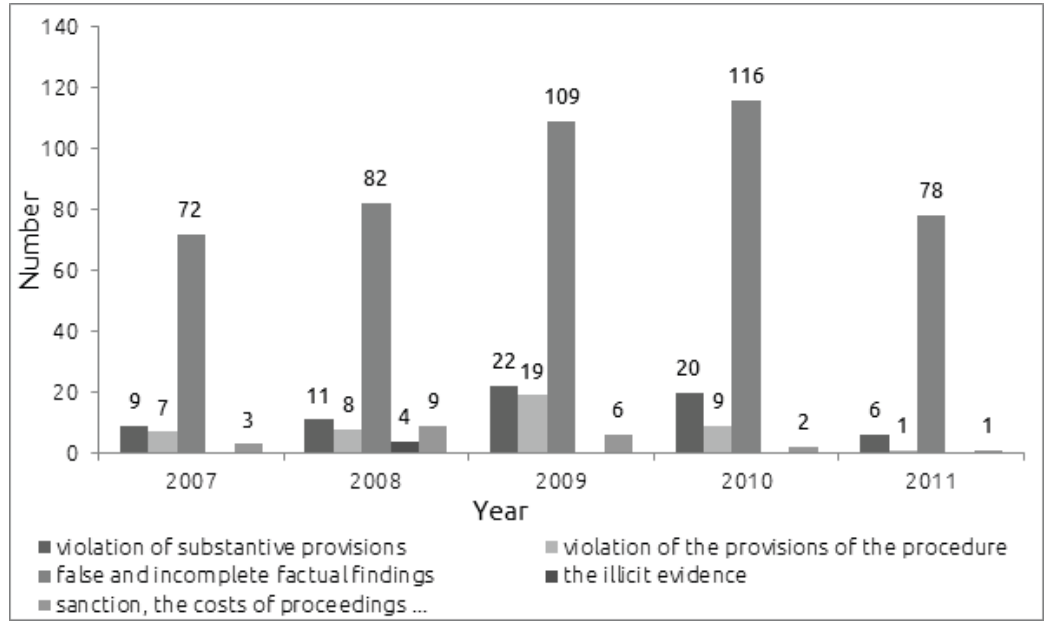

Source: JPRs filed against individual acts of the misdemeanours authority PS Kočevje

The Graph 3 shows that the reason of 'false and incomplete factual findings' is most frequently exercised by the beneficiaries in their JPRs. In the period 2007-2010 it represents somewhere between $70 \%$ and $79 \%$ of all JPRs. Only in the year 2011 there is a significant deviation, since the reason was claimed in almost $91 \%$ of all JPRs. By its frequency of being claimed, the reason of 'violation of substantive provisions' ranks second. The reason reaches its lowest percentage in 2011, because it is established only in 7\% of all JPRs, 
and its highest in 2009, when it is established in $14.1 \%$ of all JPRs. The third place is occupied by the reason of 'violation of the provisions of the procedure'. Its minimum occurred in 2011, when it was exercised only in $1.2 \%$ of all JPRs, and its maximum in 2009, when it was exercised in $12.2 \%$ of all JPRs. The reason of 'sanction, the costs of proceedings...', which occupies the fourth place, is the least established in 2011 , contributing to only $1.2 \%$ of all JPRs, and most established in 2008, in almost $8 \%$ of all JPRs. The reason of 'illicit evidence', which occupies the last, fifth place, however, was claimed only in the year 2008 , which represents $3.5 \%$ of all JPRs.

\subsection{Police Station Ribnica}

Given the fact that the Police Station Ribnica (hereinafter referred to as PS Ribnica) had received much fewer JPRs than the urban police stations, I was able to examine all of its individual acts against which a JPR was filed. That is how I got different datasets for each year (2007-2011) here as well.

Graph 4: Study of the filed JPRs by the number of the individual reason for the period 2007-2011 at PS Ribnica

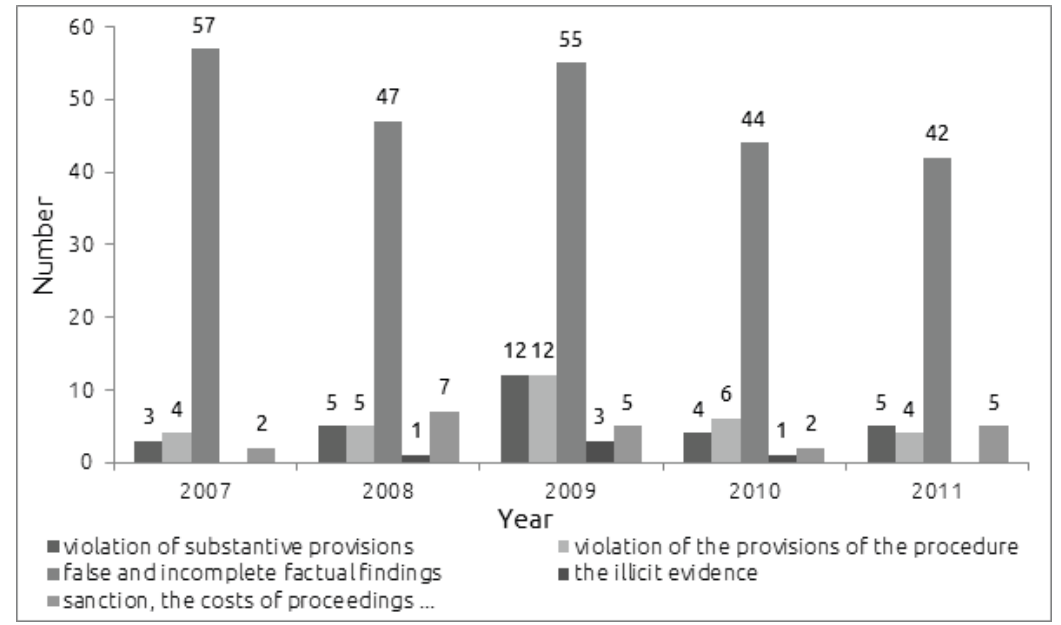

Source: JPRs filed against individual acts of the misdemeanours authority PS Ribnica

The Graph 4 also shows that the reason of 'false and incomplete factual findings' is most frequently exercised by the beneficiaries in their JPRs. The years 2007 and 2009 differ from the rest of the time periods in which it is established in between $72 \%$ and $77 \%$ of all JPRs. 2007 represents its maximum, as it was exercised in $86 \%$ of all JPRs, while 2009 is marked by its minimum, since it was established only in $63 \%$ of all JPRs. By its frequency of being claimed, the reason of 'violation of the provisions of the procedure' ranks second in almost all the studied periods. Only in 2011, the reason of 'violation of substantive provisions' takes over, but they become equally frequent in 2008 and 2009. The reason of 'violation of the provisions of the procedure' reaches its lowest percentage in 2007, because it is established 
only in $6 \%$ of all JPRs, and its highest in 2009, when it is established in $13.8 \%$ of all JPRs. When regarding all time periods in a comprehensive manner, the third most frequent reason is the 'violation of substantive provisions'. In 2011, when it ranked second, before the reason of 'violation of the provisions of the procedure', it represented nearly 9\% of all JPRs. In 2008 and 2009, when it tied with this reason, the latter is established in $7.7 \%$, or in $13.8 \%$ of all JPRs. The year 2009 thus represents its maximum, while its minimum is represented by the year 2007, when it was claimed only in $4.5 \%$ of all JPRs. The reason of 'sanction, the costs of proceedings...', which occupies the fourth place, is the least established in 2007, contributing to only $3 \%$ of all JPRs, and most established in 2008, in almost $11 \%$ of all JPRs. The reason of 'illicit evidence', which occupies the last, fifth place, however, was claimed only in the period 2008-2010, which represents between $1.5 \%$ and 3.4\% of all JPRs.

\subsection{Comparison of Results}

Individual studies indicate that there are no essential differences between the urban and regional police stations, because, irrespective of the various collected samples of units, the results are approximately the same. Hence, neither the site nor the datasets are factors which could affect the results of the study. Of course there are certain deviations from the mean at individual police stations in different time periods, which also significantly affects the final results of the conducted studies, ${ }^{17}$ so the following can be induced from these:

1. At all police stations, the first place is taken by the reason of 'false and incomplete determination of factual state', where new facts and new evidence may be proposed in the JPR only if the JPR applicant proves as likely that, without fault on his or her part, he or she could not submit them in the fast track procedure. It is claimed in the range from 59.3\% (PS Moste in 2009) to 90.7\% (PS Kočevje in 2011) with regard to all JPRs.

2. The second place is occupied by the reason of the 'violations of substantive provisions of MOA-1, or the regulation defining the offence'. The only exception is the PS Ribnica, because its analysis has shown that there the second place is occupied by the reason of the 'violation of the provisions of the procedure'. Here it should be noted that the stated reasons are quite close to one another regarding the frequency of enforcement, since they are even equally common in some periods, but overall, the reason of the 'violation of the substantive provisions' at other police stations appears in second position more frequently than the reason of 'the violation of the provisions

17 In the case of local police stations total population was analysed, which means that the resulting sample is representative. Given that the results of the conducted studies at urban and regional police stations are comparable and similar, I believe that a randomly selected sample of 150 units out of the entire population in urban stations is also representative. On the basis of these findings it can be assumed that also a new randomly selected sample of 150 units would be representative. 
of the procedure', as evidenced by their average frequency of enforcement. Thus, the runner-up reason is claimed in the range of 4.5\% (PS Ribnica in 2007) to 18.7\% (PS Moste in 2009) with regard to all JPRs.

3. The third place is filled by the reason of the 'violation of the provisions of the procedure' because a decision was not made by a competent authority, because the offender was not given an opportunity to be heard about the offence, because a person who under the law should have been excluded, or had been excluded from it, was involved in the decision making or the conduct of the procedure, because the provisions on the use of language in the procedure were infringed, because the operative part of the decision is not clear or is contradictory within itself, or because the decision does not contain all the required components. The exception is again the PS Ribnica, where the reason ranking third is the 'violation of the substantive provision'. The third reason is thus established in the range from 1.2\% (PS Kočevje in 2011) to $15.3 \%$ (PS Moste in 2009) with regard to all JPRs.

4. The fourth place goes to the reason of 'imposed sanction, asset recovery and procedural costs as well as the decision on a property claim'. It is established within a range of $1.2 \%$ (PS Kočevje in 2011) to 10.8\% (PS Ribnica in 2008). The only exception was the year 2007, when this reason was not claimed in any of the JPRs filed at the PS Center.

5. On the last, fifth place landed the reason of 'relying on a piece of evidence on which the procedure cannot rely as provisioned by the MOA-1, or which was obtained by violating human rights and fundamental freedoms set out in the Constitution'. At every police station there are at least two time frames when the reason is not claimed in any of the JPRs. Among all claims of this reason, its maximum reaches up to $3.5 \%$ (PS Kočevje in 2008).

The examined exceptions do not significantly affect the final results of the conducted study, and so I can state that the thus obtained frequency scale of the application of reasons in JPRs is present in almost all misdemeanours bodies, irrespective of their location and the sample of the collected units. Only the reasons of 'violating the substantive provision' and of 'violating the provisions of the procedure' may constitute exceptions, as has been studied in the case of PS Ribnica.

\section{Conclusion}

The analysis has shown that the amendments to the MOA-1 have actually expanded the range of grounds for challenging the decision and that a norm has been regulated, according to which it is the duty of the misdemeanours authority and the court to examine certain actionable grounds ex officio, irrespective of whether they are established in a JPR itself, or not. 
Since the Act Amendments MOA-1H and MOA-1I did not bring any changes or additions in the field of judicial protection in a fast track procedure, I can establish that in terms of JPR, the misdemeanours reform has reached the point where the Article 62 (scope of reasons) and Article 62.a of MOA-1 (examination ex officio) are regulated in a way which establishes it as a truly effective legal remedy. Now it actually fully integrates both, the elements of the right to a remedy, as well as the right to judicial protection. These are among the fundamental rights provided for by both, the ECHR and the CRS. It now covers almost all infringements that may occur during the conduct of the fast track proceedings.

The findings of the analysis are intended for the beneficiaries of JPR as well as for the misdemeanours authorities. Beneficiaries can now lodge a JPR on the grounds of any irregularity which has been, according to their belief, committed by the misdemeanours authority in the conduct of the fast track procedure. In the past, the illicit evidence was missing among the reasons (fourth indent of Article $62 \S 1$ of MOA-1). During this time, other reasons experienced only small corrections and additions. Beneficiaries are now ensured with a some kind of a double safety measure. Some actionable grounds are now by obligation examined by misdemeanours authority and court ex officio, irrespective of whether they have been established with a JPR. In the past, this obligation was not regulated, which meant that they only examined those reasons which have been applied in a JPR. With JPR regulated in this way, the beneficiaries are now much more likely to succeed with it, especially before the court, in comparison with its regulation in the past.

Since JPR is an effective remedy now, the conduct of a misdemeanours authority is now even more closely monitored. Beneficiaries have now more actionable grounds available, which enable them to lodge a JPR, if they believe that any irregularity has been committed during the conduct of a fast track procedure. In the study I presented a scale showing the frequency of filing a challenge on the grounds of an individual reason. On the basis of the examination of the selected samples I have found that the frequency of their application does not change much within the selected time frames at police stations. This suggests that the samples of 150 units, which were randomly selected from the entire population at urban police stations, are representative, and that such results can be anticipated at other police stations as well, in the event that the study expands and includes them. The information which of the reasons is most often established enables the misdemeanours authority to realize in which part of its fast track procedure most irregularities are claimed. In this way, the authority can already in the present undertake certain measures to avoid these irregularities, which means a greater legality of its conduct, handling and decision-making in the future, and consequently, the prevention of beneficiaries claiming these reasons. It is not surprising, that precisely the reason of inaccurate and incomplete 
findings of factual state, among all others, is far the most commonly claimed reason in JPR. This can be attributed to the fact that on the one hand we have the established factual state advocated by the misdemeanours authority, while on the other hand there is a factual state advocated for by the alleged offender. When the decision does not take into account the offender's point of view and it also does not explain it, this constitutes the baseline point for most of the filed JPR claiming the mentioned reason. Even the Police misdemeanours authority in their decisions often do not declare the statements of the offender, or the latter are very limited. Considering this kind of conducting a fast track proceedings, it is quite logical that the offender, who is accused of an offence, feels that the procedure was conducted unilaterally, since his statements were not considered, or were taken into account only to a lesser extent. This all points to an apparent violation of the right to a fair trial (Article 6 of ECHR and Articles 22, 23 and 25 of CRS).

To avoid such violations, the misdemeanours authority must be aware of the importance of the above, and in this part of the fast track procedure pay additional attention and undertake certain measures to improve the situation in this area. I suggest the following:

- Adversarial procedure - is one of the elements of the right to a fair trial. Based on my own experience, I can state that only in the last year has the Police misdemeanours authority become aware of the importance of ensuring adversary in fast track proceedings. Only when the offender has learned of all the collected facts, circumstances, evidence and witnesses statements, may he or she take a position on the legal and factual aspects of the offence committed. Even if the misdemeanours body collects new, additional facts and evidence, it is required of the body to again notify the offender. If the offender takes a stand regarding the offence committed, then the misdemeanours authority is familiarized with his or her actual material scope. Only a fast track procedure conducted in this way allows us to adopt an authentic, correct, legal decision which takes into account the positions of both, the offender and the misdemeanours authority.

- Self-criticism - forcefully conducting a fast-track procedure. In case there is any doubt that someone may not have committed an offence, or that there exist circumstances which preclude prosecution for the offence, the misdemeanours authority must be sufficiently selfcritical about its operation and determine in these cases, whether the conditions are met to accuse someone of an offence and also issue the appropriate individual act (payment order, the decision on the offence).

- Training - due to the constantly changing nature of MOA-1, effective JPR, and case law, a continuous training of all those involved in the fast track proceedings is required, because only qualified staff can be expected to lower the number of complaints regarding the irregularities in the conduct of fast track procedure. Maybe it would be 
necessary to enact an annual mandatory training for officers working in misdemeanours bodies (especially for those with bachelor or master degrees, since they are more susceptible to the complexity of the fast track procedure); the training would present new amendments, common irregularities or maybe even a more rigorous rule would be needed, requiring, for example to pass a test on the conduct of a fast track procedure every three years. In current situation many officers are inadequate to conduct a fast track procedure at the level which is currently required. Also, a selection should be implemented to actually ensure that only those conduct fast track procedures who have proven through the tests that they are adequate to conduct these proceedings on such a level. If someone has obtained a bachelors degree or higher, it does not necessarily guarantee that this person is suitable for such a demanding task of managing fast track proceedings.

- Taking into account the decisions of the Constitutional Court, no. Up-34/93 and Up-13/94, which, inter alia, in relation to the fast track procedure state that the misdemeanours body, according to the principle of free evaluation of evidence and the principle of material truth, shall alone decide on which evidence will be taken into consideration and how it will assess their credibility. At the same time, it is not obliged to take all the evidence proposed by the defence. Its duty is only to explain why the proposed evidence was not accepted. In this way, the offender will be also provided the constitutional right to present evidence in his or her favour (third indent of Article 29 of CRS).

Of course, it would be illusory to expect that the beneficiaries would no longer lodge JPRs due to erroneous and incomplete findings of fact, but I believe that by applying the above proposals, it would be possible to reduce the frequency of lodging.

The MOA-1 in Article $55 \S 1$ provides that the misdemeanours authority ex officio and without delay quickly and simply determines those facts and gathers the evidence which are necessary to make a decision on the offence. This raises the question whether such an arrangement still makes any sense, given the fact that misdemeanours proceedings, and consequently the determination of factual state, have become complex and time-consuming rather than quick and simple. I suggest an amendment of that provision, since it would be necessary to determine what the facts are, as well as divide them into decisive and other relevant facts, which are the pieces of evidence and what is their scope, what is material truth and the importance of searching for it at different stages of the proceedings, what are the legal and actual questions, what is the standard of proof and its degrees (e.g. in criminal proceedings the standard of proof consists of six levels), what is the evidence ban, what is the instructing maxim. These are only a few postulates which shall lead a misdemeanours authority through the various stages of the fast track procedure. Their importance would come to the fore especially in determining 
the factual state, since taking them into account would allow us to determine its completeness or at least its approximation. In short, the MOA-1 should define what is entailed in the determination of the factual state.

The results of the study on the frequency of claiming an individual reason when lodging JPR indicate a need for further research, since the survey examined certain areas only. It would be certainly useful to further explore the findings of the actual success of beneficiaries regarding their claims of individual reasons when filing a JPR. After the completion of such study, it would be possible to determine how many of these JPRs, with regard to the individual claimed reason, were unfounded, and how many decisions by a misdemeanours body have been modified or ceased. This kind of study would provide us with the information about the actual success of the beneficiaries when challenging a singular act (payment order, decision, conclusion) by lodging a JPR in relation to a claimed reason.

Tine Jurič holds Master Degree (Master of Administrative Sciences). He is the Assistant Chief of Police Station for compensatory measures Ljubljana. His working areas are primarily research and detection of misdemeanour and crimes. He has published several professional articles. The article "Analysis of the set, meaning, range and frequency of lodging the reasons for judicial protection request" is his first scientific article. His work has been praised many times, he has received the award "Bronze shield of the Police" for all outgoing achievements. Now he continues his PhD study at the Faculty of Government and European Studies. His area of research is misdemeanor law. 
Analysis of the Set, Meaning, Range and Frequency of Lodging the Reasons for Judicial Protection Request

\section{References}

\section{Literature}

Craig, P. (2003). Administrative Law. London: Sweet and Maxwell.

Fišer, Z. (2006). Sodnik v postopku o prekršku. In 1. dnevi prekrškovnega prava (pp. 49-57). Ljubljana: GV založba.

Gajzer, M. (2007). Varstvo človekovih pravic v postopkih pred sodišči. In 2. dnevi prekrškovnega prava (str. 156-162). Ljubljana: GV založba.

Jakulin, V.(2007). Dejansko stanje pri plačilnem nalogu. In 2. dnevi prekrškovnega prava. Ljubljana: GV založba.

Jenull, H. (ur.), Čas, P., Filipčič, K., Fišer, Z., Maček Guštin, Š., Orel, N., Perpar, M., \& Selinšek, L. (2009). Zakon o prekrških s komentarjem. Ljubljana: GV založba.

Jenull, H., \& Selinšek, L. (2011). Uvodna pojasnila k ZP-1 z novelama ZP-1F in ZP1G. Ljubljana: GV Založba.

Kečanović, B. (2010). Pet let reforme prekrškovnega prava. Pravna praksa, 29(25), p. 1.

Kovač, P. (2012). Pomen in raba pravnega sredstva odprave in spremembe odločbe na predlog prekrškovnega organa. Pravosodni bilten, 33(1), 87-99.

Maunz, T., \& Dürig, G., (1991). Grundgesetz Kommentar. München: C. H. Beck.

Nehl, H. P. (1999). Principles of Administrative Procedure in EC Law. Oxford: University of Oxford.

Orel, N. (2008). Razlogi za vložitev zahteve za sodno varstvo. In 3. dnevi prekrškovnega prava (pp. 28-34). Ljubljana: GV založba.

Šturm, L. (ur.), Arhar, F., Blaha, M., Bučar, F., Čebulj, J., Deisinger, M., Dular, J., Friedl, J., Graselli, A., Jadek Pensa, D., Jaklič, K., Jambrek, P., Jerovšek, A., Klemenčič, G., Končina Peternel, M., Kresal, B., Mavčič, A. M., Mozetič, M., Novak, M., Orehar Ivanc, M., Pemuš Grošelj, B., Pirnat, R., Plauštajner, K., Ribarič, M., Rijavec, V., Sladič, J., Sovdat, J., Steinman, T., Šorli, M., Testen, F., Toplak, L., Trampuž, M., Trpin, G., Virant, G., Vlaj, S., Zakrajšek, F., Zalar, B., \& Zupančič, M. B. (2002). Komentar Ustave Republike Slovenije. Ljubljana: Fakulteta za podiplomske državne in evropske študije.

Šturm, L. (ur.), Avbelj, M., Bardutzky, S., Bele, I., Blaha, M., Cerar, M., Čebulj, J., Deisinger, M., Galič, A., Grad, F., Ivanc, B., Jaklič, K., Jakulin, V., Jambrek, P., Jerovšek, T., Kaučič, I., Končina Peternel, M., Kovač, P., Klemenčič, G., Kresal, B., Letnar Černič, J., Mavčič, A., Nerad, S., Orehar Ivanc, M., Pavlin, P., Pirnat, R., Pogorelec, J., Prepeluh, U., Farmany, P., Sovdat, J., Šorli, M., Testen, F., Umek, U., Vlaj, S., Zagradišnik, R., Zobec, J., \& Zupančič, K. (2011). Komentar Ustave Republike Slovenije: dopolnitev - A. Ljubljana: Fakulteta za podiplomske državne in evropske študije.

\section{Sources}

(1994). Evropska konvencija o človekovih pravicah (EKČP). Ur. list RS, št. 33/94, MP, št. 7/94).

(1991). Ustava Republike Slovenije. Ur. list RS, št. 33/91, 42/97, 66/00, 24/03, $69 / 04,68 / 06$. 
(1994). Zakon o kazenskem postopku (ZKP). Ur. list RS, št. 63/94 (70/94 popr.), 25/96 Odl.US: U-I-18/93, 39/96 Odl.US: U-I-33/95-12, 5/98 Odl.US: U-I-25/95, 49/98-ZPol (66/98 рорг.), 72/98, 6/99, 42/00 Odl.US: U I 282/99, 66/00, 111/01, 32/02 Odl.US: U-I-92/96-27, 3/03 Odl.US: U-I-204/99-22, 21/03 Odl. US: U-I-190/00-11, 44/03 Odl.US: U-I-149/99-15, 56/03, 92/03 Odl.US: U-I319/00-21, 114/03 Odl.US: U-I-426/02, Up-546/01-21, 116/03-UPB1, 43/04, 68/04 Odl.US: U-I-296/02, 83/04 Odl.US: Up-729/03, U-I-187/04, 96/04-UPB2, 101/05, 8/06-UPB3, 14/07, 32/07-UPB4, 102/07-ZSKZDČEU, 21/08 Odl.US: U-I-96/06-13, 23/08-ZBPP-B, 65/08 Odl.US: U-I-328/04-22, 68/08, 89/08 Odl. US: U-I-25/07-43, 77/09, 88/09 Odl.US: Up-3871/07-26, U-I-80/09-26, 109/09 Odl.US: U-I-46/08-20, 29/10 Odl.US: U-I-50/09-18, Up-260/09-17, 58/11-ZDT-1, 91/11, 32/12-UPB8, 47/13.

(1999). Zakon o splošnem upravnem postopku (ZUP). Ur. list RS, št. 80/99, 70/00, 52/02, 73/04, 22/05-UPB1, 119/05, 24/06-UPB2, 105/06-ZUS-1, 126/07, 65/08, 47/09 Odl.US: U-I-54/06-32 (48/09 рорг.), 8/10.

(2003). Zakon o prekrških (ZP-1). Ur. list RS, št. 7/2003, št. 86/2004, 7/2005 Skl. US: U-I-19/05-5, 23/2005-UPB1, 34/2005 Odl.US: U-I-19/05-11, 44/2005, 55/2005-UPB2, 40/2006 (51/2006 рорг.), 70/2006-UPB3, 115/2006, 139/2006 Odl.US: U-I-69/06-16, 3/2007-UPB4, 29/2007 Odl.US: U-I-56/0631, 58/2007 Odl.US: U-I-34/05-9, 16/2008 Odl.US: U-I-414/06-7, 17/2008 (21/2008 рорг.), 76/2008-ZIKS-1C, 108/2009, 109/2009 Odl.US: U-I-56/0815, 45/2010-ZIntPK, 9/2011, 10/2011 Odl.US: Up-319/10-14, U-I-63/10-7, 26/2011 Odl.US: Up-456/10-22, U-I-89/10-16, 29/2011-UPB8, 43/2011 Odl. US: U-I-166/10-8, 21/2013, 111/2013.

(2006). Zakon o varstvu javnega reda in miru (ZJRM-1). Ur. List RS, št. 70/2006.

(2010). Zakon o pravilih cestnega prometa (ZPrCP). Ur. list RS, št. 109/2010, 57/2012.

Sodba ESČP, Suhadolc proti Sloveniji, 17.5.2011, vloga št. 57655/08.

Sodba ESČP, Šild proti Sloveniji, 17. 9. 2013, vloga št. 59284/08.

Odločbi Ustavnega sodišča RS, št. Up-34/93 in Up-13/94, 8. 6. 1995.

Odločba Ustavnega sodišča RS, št. U-I-56/06-31, 15. 3. 2007.

Odločba Ustavnega sodišča RS, št. Up-1293/10, 21. 6. 2012.

Sodba Vrhovnega sodišča RS, št. IV Ips 41/2006, 16. 2. 2007.

Sodba Vrhovnega sodišča RS, št. IV Ips 58/2007, 28. 2. 2008.

Sodba Vrhovnega sodišča RS, št. IV Ips 71/2007, 16. 9. 2008.

Sodba Vrhovnega sodišča RS, št. IV Ips 117/2008, 24. 2. 2009.

Sodba Vrhovnega sodišča RS, št. IV Ips 41/2013, 25. 4. 2013.

Sodba Vrhovnega sodišča RS, št. IV Ips 28/2014, 20. 5. 2014.

Sodba Višjega sodišča v Ljubljani, št. VSL PRp 571/2009, 24. 3. 2009.

Sklep Višjega sodišča v Celju, št. VSC Prp 241/2013, 17. 1. 2014. 